\title{
Purification of Tomato Spotted Wilt Virus Isolated from Tobacco Plants in Morioka, Japan*
}

\author{
Shinya TsudA ${ }^{* * \dagger}$, Keiko T. NATSUAKI*** and Keiichi ToMARU**
}

\begin{abstract}
A virus isolated from tobacco plants in Morioka was confirmed as tomato spotted wilt virus (TSWV) and designated as TSWV-M isolate. The virus shows severe symptoms on several plants including tobacco, tomato and Nicotiana benthamiana. TSWV-M was used for the purification study. Out of seven kinds of buffers for extraction of TSWV, $0.1 \mathrm{M}$ phosphate buffer containing $0.01 \mathrm{M} \mathrm{Na}_{2} \mathrm{SO}_{3}$ and $0.01 \mathrm{M}$ EDTA.2Na was suitable with high infectivity in crude sap checked by half-leaf method using $N$. tabacum cv. Xanthi nc. In a purification method with isopycnic linear sucrose density gradient with concentration from $15.0 \%$ to $60.0 \%(\mathrm{w} / \mathrm{w})$, the peak fraction of TSWV infectivity was indicated at $42.0 \%$ (w/w) sucrose fraction. By this method, however, the host components could not be eliminated from the peak fraction. In isopycnic step-wise sucrose density gradient method with trap of $40.0 \%(\mathrm{w} / \mathrm{w})$, host components could be excluded from $42.0 \%(\mathrm{w} / \mathrm{w})$ sucrose fraction with high infectivity. Intact TSWV particles were observed in the fraction by the electron microscopy. With the passage of the TSWV purification process, specific infectivities in the final step were calculated as 44 times at $\mathrm{OD}_{260}$ and 46 times higher at $\mathrm{OD}_{280}$ in the ratio to the first step preparation.
\end{abstract}

(Received August 20, 1990)

Key words: tomato spotted wilt virus, purification, isopycnic linear sucrose density gradient, isopycnic step-wise sucrose density gradient, specific infectivity.

\section{INTRODUCTION}

Tomato spotted wilt virus (TSWV), which has very wide host range ${ }^{2)}$, causes severe chlorotic, necrotic and malformed symptoms on host plants in tropical, sub-tropical and temperate zones ${ }^{9,13)}$ and is transmitted by thrips ${ }^{1,18)}$. In Japan, TSWV causes damages to tomato ${ }^{12,25)}$, tobacco ${ }^{22,23)}$, green pepper ${ }^{19)}$, dahlia ${ }^{8)}$ and watermelon ${ }^{9}$.

TSWV particle is constructed with ribonucleic acid ${ }^{26,27)}$, protein ${ }^{17,20)}$, phosphorus and lipid. Electron micrographs of ultrathin sections of infected leaves ${ }^{7,14,15)}$ and negatively stained infected leaf sap $^{5}$, show the virus particles with envelope. The virus particles are spherical with spike structure on the envelope and their diameters are about $85 \mathrm{~nm}$. Recently, TSWV is classified to Bunyaviridae from the characteristics of the virus ${ }^{16)}$.

Since organic solvents and/or surface-active agents have been used for purification of ordinary plant viruses, both reagents can not be used for TSWV. Joubert et al. ${ }^{10)}$ purified TSWV

* A part of this work was reported at the 5th International Congress of Plant Pathology, Kyoto, 20-27 August, 1988, Japann ${ }^{24)}$. This study was supported in part by Grant-in-Aid for Scientific Research (No. 01304013) from Ministry of Education, Science and Culture of Japan.

** NODAI Research Institute, Tokyo University of Agriculture, Sakuragaoka, Setagaya-ku, Tokyo 156, Japan 東京農業大学総合研究所

*** Laboratory of Tropical Plant Protection, Faculty of Agriculture, Tokyo University of Agriculture, Sakuragaoka, Setagaya-ku, Tokyo 156, Japan＼cjkstart東京農業大学農学部熱帯作物保護研究室

$\dagger$ †resent address: Rokkō Bio-Scientific Research Laboratory, Tsurugasone, Yashio, Saitama 340, Japan 現在：鹿光生物科学研究所 
fixed with glutaraldehyde by electrophoresis with column after sucrose density gradient centrifugation. On the other hand, Tas et al. ${ }^{20)}$ reported that TSWV was purified by excluding host components using antisera to host components. Other purification methods may not have succeeded in purification of particles coated with envelope ${ }^{2,3,11,17,18}$. This report demonstrates a method of purification to obtain the intact TSWV with high infectivity using step-wise sucrose density gradient.

\section{MATERIALS AND METHODS}

Virus and plants. TSWV-M isolated from tobacco in Morioka, Japan in 198321) was used in this study. This virus was mechanically inoculated to several differential host plants. Plants for inoculation were grown in a glass chamber at $25^{\circ} \mathrm{C}$ for $16 \mathrm{hr}$ light and $20^{\circ} \mathrm{C}$ for $8 \mathrm{hr}$ dark periods with $60-70 \%$ humidity. Inoculation buffer was $0.1 \mathrm{M}$ phosphate buffer (PB) pH 7.0 with $0.01 \mathrm{M} \mathrm{Na}_{2} \mathrm{SO}_{3}$.

Electron microscopy. TSWV-M infected sap of Nicotaina tabacum cv. Xanthi nc leaves was treated with $5 \%(\mathrm{v} / \mathrm{v})$ glutaraldehyde and mounted on grids coated with a collodion film, and stained with $2 \%(\mathrm{w} / \mathrm{v})$ phosphotungstic acid $\mathrm{pH} 7.0$ as previously described ${ }^{5,6,14)}$. Samples for ultrathin sections were obtained from systemically infected tobacco ( $N$. tabacum cv. Burley 21) leaves, which showed systemic symptoms in 5-6 days after inoculation. Uranyl acetate and lead citrate were used for staining in ultrathin sections. Examinations were done on a JEM-1200 EX electron microscope.

Extraction buffer. Seven kinds of buffers (Table 1) were compared using the same plant source at the same time. Three grams of infected leaf pieces were homogenized in 27 $\mathrm{ml}$ of each extraction buffer with mortars and pestles. Their crude sap were filtered through two layers of aseptic gauze and centrifuged at $10,000 \times g$ for $10 \mathrm{~min}$. Supernatants and the precipitates were separately resuspended in $1 \mathrm{ml}$ of $0.1 \mathrm{M} \mathrm{PB}$ with $0.01 \mathrm{M} \mathrm{Na}_{2} \mathrm{SO}_{3}$. These crude sap, supernatants and precipitates were inoculated to leaves of tobacco (N. tabacum cv. Xanthi nc) for infectivity assay with half-leaf method.

Purification of TSWV. Upper leaves of infected tobacco (N. tabacum cv. Burley 21) with typical TSWV symptoms in 4-5 days after inoculation were used as materials for virus purification. Isopycnic sucrose density gradient method in final step was used either linear or step-wise gradients for comparison. Purification of TSWV was performed according to the procedure shown in Fig. 1. All works were done in the cold room at $4^{\circ} \mathrm{C}$.

Infectivity assay and purity check. Every fraction after each centrifugation step of isopycnic sucrose density gradient was measured by spectrophotometer at $\mathrm{OD}_{260}$ and $\mathrm{OD}_{280}$ and quantitatively assayed by inoculation to tobacco leaves (Xanthi nc) in half-leaf method using crude sap of systemically infected tobacco leaves as control, respectively. The fraction with the highest TSWV infectivity was observed with direct negative staining method by electron microscope. The recovery of TSWV from each step was measured by spectrophotometer at $\mathrm{OD}_{260}$ and $\mathrm{OD}_{280}$ and assayed by infectivity test.

\section{RESULTS}

\section{Symptoms of differential host plants}

Tomato (Lycopersicon esculentum cv. Fukuju-2) showed local necrotic lesions in 4-5 days after sap inoculation and systemic symptoms including malformation and curling of leaves, in 8-10 days, followed by severe mosaic, necrosis and stunting. $\quad N$. tabacum cv. Burley 21 showed local lesions on the inoculated leaves and systemic symptoms that appeared yellowing along veins, followed by mosaic symptoms. Finally, the plants died with severe necrosis (Plate I-1). Inoculated leaf of $N$. tabacum cv. Xanthi nc indicated many necrotic lesions with chlorotic rings (Plate I-2), then systemic yellowing and mosaic appeared. Chlorotic local lesions on inoculated 


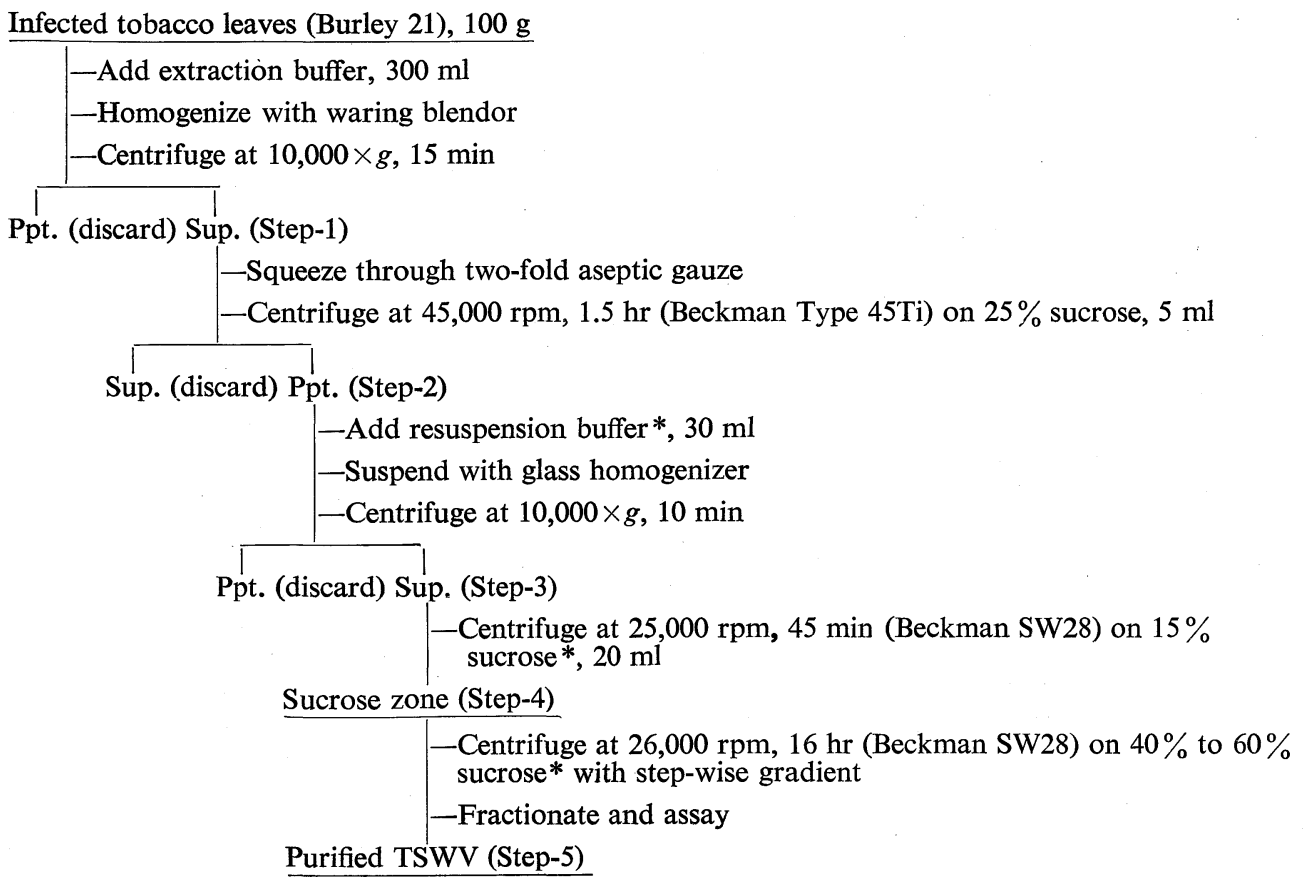

Fig. 1. Procedure of TSWV purification. *: $0.02 \mathrm{M} \mathrm{PB} \mathrm{pH} 7.0$ contained $0.01 \mathrm{M}$ EDTA.2Na and $0.1 \%(w / v)$ L-cysteine.

leaf of $N$. benthamiana appeared in 4-5 days after inoculation, followed by yellowing. Petunia hybrida (Pearlmix) showed only necrotic local lesions on inoculated leaves, in 3-4 days after inoculation. Inoculated leaf of Vigna sesquipedalis showed faint chlorotic ring spots in 5-6 days after inoculation, and followed by systemic yellowing and necrosis.

\section{Electron microscopy}

TSWV-M particles with envelope were observed in sap of infected tobacco cv. Xanthi nc (Plate I-3). Most of TSWV particles were coated with spike structural envelope around the core. The particles were about $85 \mathrm{~nm}$ in diameter and spherical cores with high electron density were about $60 \mathrm{~nm}$ in diameter. In mesophyll cells of systemically infected tobacco cv. Burley 21 leaves, many TSWV particles were observed inside the membrane-like structure in cytoplasm by ultrathin sectioning (Plate I-4). Most of the virus particles were recognized as intact.

\section{Purification of virus}

Effects of extraction buffers for extraction of TSWV-M from infected leaf tissues were shown in Table 1. Infectivities of crude sap homogenated with each buffer were shown in any buffers, respectively. Homogenate using $0.1 \mathrm{M}$ PB containing $0.01 \mathrm{M}$ EDTA $2 \mathrm{Na}$ kept the higher infectivity in the supernatant after centrifugation than other buffer solutions tested. The effect of buffer containing $\mathrm{MgCl}_{2}$ on the infectivity was not observed. Consequently, $0.1 \mathrm{M}$ PB pH 7.0 containing $0.01 \mathrm{M} \mathrm{Na}_{2} \mathrm{SO}_{3}$ and $0.01 \mathrm{M}$ EDTA.2Na was used in the following purification.

Comparison with both linear and step-wise isopycnic sucrose density gradients after centrifugation were shown in Fig. 2. The infectivity in each purification process was shown to be the highest at $42.0 \%(\mathrm{w} / \mathrm{w})$ sucrose concentration in linear gradient. This peak of infectivity, however, was included into broad peak from $33.6 \%$ to $38.6 \%(\mathrm{w} / \mathrm{w})$ when measured at $\mathrm{OD}_{260}$ and $\mathrm{OD}_{280}$. Therefore, as host components were contaminated to this fraction, no single narrow peak of TSWV was obtained. In electron microscopic observation, host components accompanied with TSWV particles were observed in this fraction. However, step-wise gradient formed 
Table 1. Comparison of extraction buffers for TSWV purification measured by infectivity on tobacco leaves

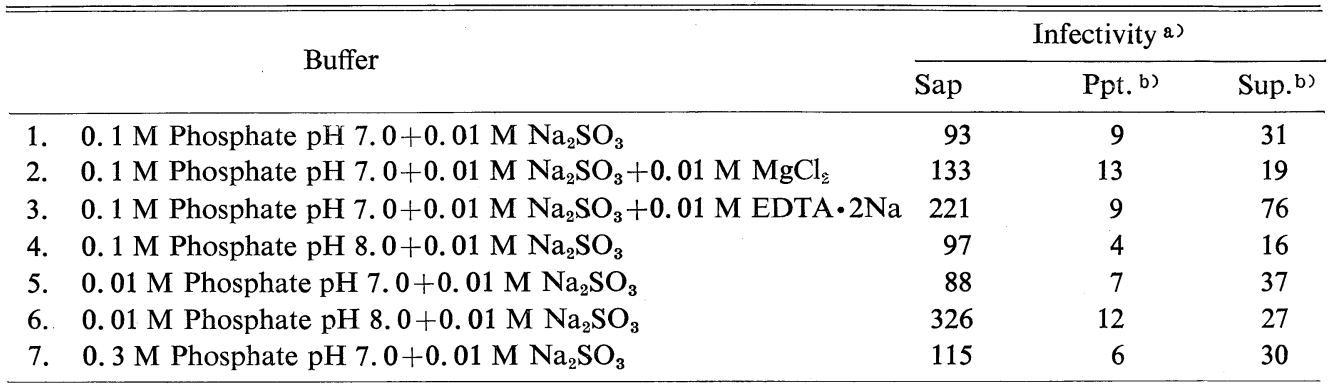

a) Infectivity is expressed by relative value in percentage, the number of local lesions on the 3 inoculated half leaves of N. tabacum cv. Xanthi nc per a test divided by the number of local lesions on the other half leaves inoculated with control leaf sap in $0.1 \mathrm{M} \mathrm{PB}$ containing $0.01 \mathrm{M} \mathrm{Na}_{2} \mathrm{SO}_{3}$.

b) Precipitates (Ppt.) and supernatants (Sup.) after centrifugation of crude sap (Sap) at 10,000 $\times g, 10 \mathrm{~min}$.
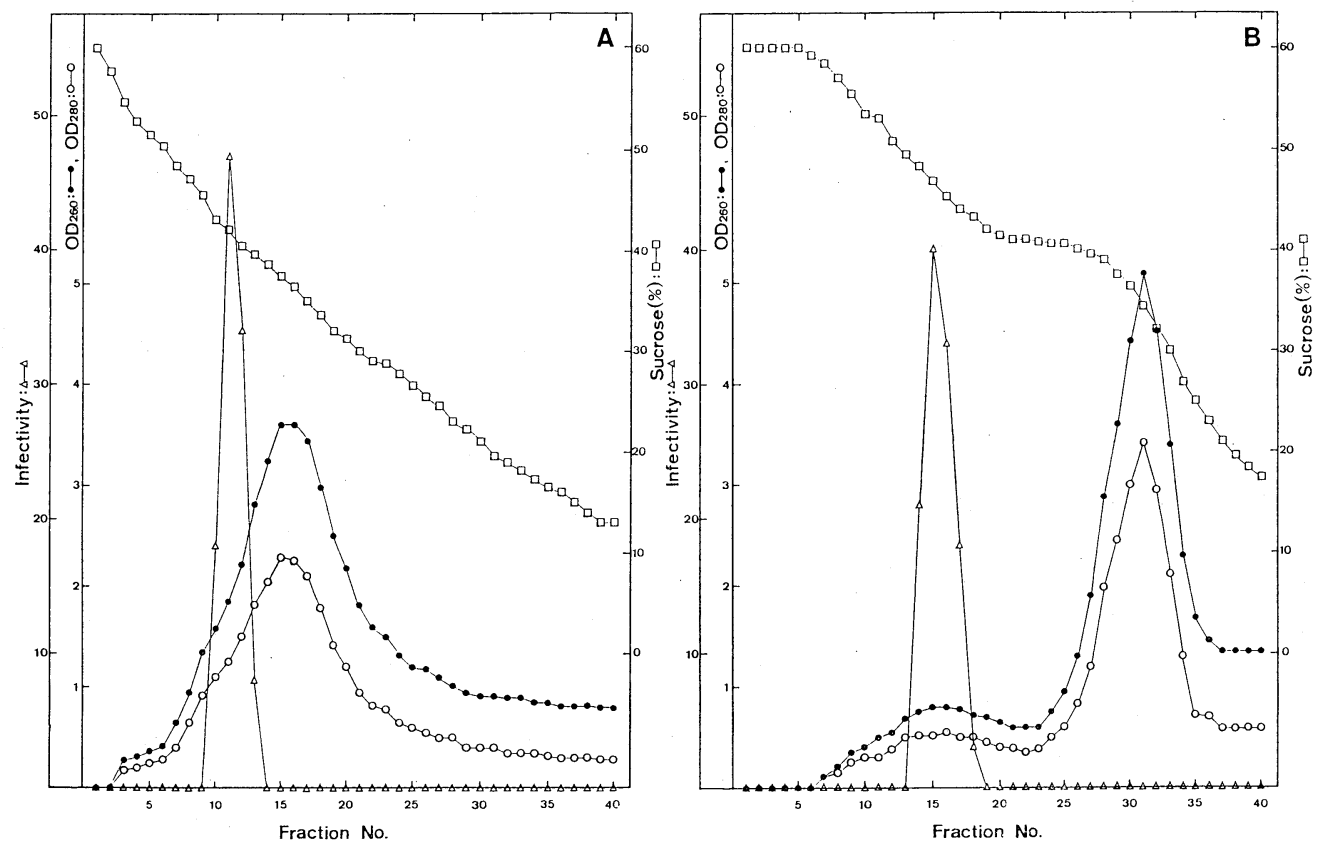

Fig. 2. Fractionations of TSWV by ulcracentrifugation in isopycnic inear sucrose density gradient from $15 \%$ to $60 \%(\mathrm{w} / \mathrm{w})$ sucrose concentration (A) and isopycnic step-wise sucrose density gradient of $15 \%, 40 \%$ and $60 \%(w / w)$ sucrose concentration (B).

$40.0 \%(\mathrm{w} / \mathrm{w})$ sucrose step as trap could divide TSWV peak at $42.0 \%(\mathrm{w} / \mathrm{w})$ from host components peak at $37.0 \%(\mathrm{w} / \mathrm{w})$.

\section{Electron microscopy of purified virus}

The virus particles were observed by electron microscope using negative staining (Plate I-5). Most of TSWV particles were coated with envelope around the core.

\section{Recovery of virus}

Recovery of virus in each purification step was shown in Table 2. The infectivity was detected in all steps except in step 2. Absorbencies at $\mathrm{OD}_{260}$ and $\mathrm{OD}_{280}$ were increased, with the 
Table 2. Recovery of TSWV from each purification step

\begin{tabular}{|c|c|c|c|c|c|}
\hline & Step 1 & Step 2 b) & Step 3 & Step 4 & Step 5 \\
\hline Volume (ml) & 246 & 256 & 25 & 40 & 4 \\
\hline Infectivity a) & 33 & 0 & 155 & 61 & 28 \\
\hline $\mathrm{OD}_{260}$ & 39.8 & 30.3 & 9.3 & 1.6 & 0.8 \\
\hline $\mathrm{OD}_{280}$ & 28.3 & 21.5 & 5.0 & 0.9 & 0.5 \\
\hline $\mathrm{OD}_{260} / \mathrm{OD}_{280}$ & 1.41 & 1.41 & 1.86 & 1.92 & 1.46 \\
\hline \multicolumn{6}{|c|}{ Specific infectivity } \\
\hline Infec./OD ${ }_{260}$ & 0.83 & 0.00 & 16.67 & 37.42 & 36.84 \\
\hline (ratio/Step 1) & 1.00 & 0.00 & 20.08 & 45.08 & 44.39 \\
\hline Infec./OD 280 & 1.17 & 0.00 & 31.00 & 71.76 & 53.85 \\
\hline (ratio/Step 1) & 1.00 & 0.00 & 26.50 & 61.33 & 46.03 \\
\hline \multicolumn{6}{|c|}{ Total relative quantity of TSWV } \\
\hline Infec. $\times$ vol. & 8118 & 0 & 3798 & 2440 & 112 \\
\hline$(\%)$ & 100.0 & 0.0 & 46.8 & 30.1 & 1.4 \\
\hline Infec. $\times \mathrm{OD}_{260}$ & 9798 & 0 & 228 & 65 & 3 \\
\hline$(\%)$ & 100.0 & 0.0 & 2.3 & 0.7 & 0.1 \\
\hline Infec. $\times \mathrm{OD}_{280}$ & 6962 & 0 & 123 & 32 & 2 \\
\hline$(\%)$ & 100.0 & 0.0 & 1.8 & 0.5 & 0.1 \\
\hline
\end{tabular}

a) Infectivity is expressed by relative value as described in footnote of Table 1.

b) Discarded supernatant was measured.

passage of the purification process, and specific infectivities, measured by infectivity per unit UV optical density, in the final step were calculated as 44.4 times at ${ } D_{260}$ and 46.0 times higher at $\mathrm{OD}_{280}$ in the ratio to the first step preparation. Total relative amounts of virus, which were calculated by infectivity multiplied by volume $(\mathrm{ml}), \mathrm{OD}_{260}$ or $\mathrm{OD}_{280}$, respectively, were decreased gradually. Considerable amounts of TSWV included in plants were lost through the purification process.

\section{DISCUSSION}

It is clear that TSWV-M is different from another isolate obtained from tobacco plants in Okinawa (TSWV-R) ${ }^{22,23)}$ which shows yellow mottle without severe necrosis on tobacco plants. Host range of TSWV has been reported that covers 157 species of 29 families in dicotyledons and 6 species of 5 families in monocotyledons ${ }^{2}$, and symptoms have been recorded in detail. The symptoms of plants inoculated with TSWV-M are similar to those reported previously $\mathrm{y}^{2,6,8)}$ except TSWV- $\mathrm{R}^{23)}$ and watermelon isolates ${ }^{9)}$ which also show similar symptoms to TSWV-R. P. hybrida and N. tabacum cv. Xanthi nc are useful for assay plants. N. tabacum and $N$. benthamiana are suitable as source plants for purification.

Particles of TSWV-M with envelope in membrane-like structure were observed by ultrathin sectioning as reported previously?

Purification of TSWV is known to be rather difficult ${ }^{4,23}$. There are several reasons and one reason is that TSWV is inactivated in vitro within $2-5 \mathrm{hr}$ at room temperature ${ }^{4}$. The other reason is that as TSWV was coated with envelope which consisted of lipid, phosphorus and protein ${ }^{17,20)}$, and organic solvents and/or surface-active agents which are usually used for plant virus purification are not applicable to obtain intact TSWV and to remove host components.

Mohamed et al. ${ }^{17)}$ used rate-zonal linear sucrose density gradient method from $10.0 \%$ to $40.0 \%(\mathrm{w} / \mathrm{v})$ sucrose concentration instead of organic solvent and/or surface-active agent. Joubert et $a l .^{10}$ ) used zone electrophoresis of the column in fixing treatment with glutaraldehyde, linear sucrose density gradient of $10.0 \%$ to $40.0 \%$ (w/v). Since TSWV fixed with glutaraldehyde 
lost the biological activities, infectivity of purified virus have not been checked. Tas et al. ${ }^{20)}$ used antisera against host components for elimination of host components from partially purified virus suspension. This method showed poor separation between the virus and host components by our preliminary test. In the present study, sucrose density gradient was modified for excluding components of host plants. Sample contained TSWV was centrifuged on $15.0 \%(\mathrm{w} / \mathrm{w})$ to $60.0 \%(\mathrm{w} / \mathrm{w})$ isopycnic step-wise sucrose density gradient for $16 \mathrm{hr}$. This gradient tube was formed sucrose step on $40.0 \%(\mathrm{w} / \mathrm{w})$ as a trap to separate TSWV from host components. After centrifugation, two peaks of absorbencies at $\mathrm{OD}_{260}$ and $\mathrm{OD}_{280}$ appeared on $42.0 \%(\mathrm{w} / \mathrm{w})$ and $38.5 \%(\mathrm{w} / \mathrm{w})$, respectively. The peak on $42.0 \%(\mathrm{w} / \mathrm{w})$ had high infectivity on tobacco leaves and also contained many intact TSWV particles with envelope observed under the electron microscope. From these results, this method is useful for TSWV purification. This isopycnic step-wise sucrose density gradient, however, took long time (more than $15 \mathrm{hr}$ ) and unstable viruses like TSWV may lost some infectivity. Though the estimated amounts of virus decreased in each passage of this purification process, specific infectivity was shown to increase. Therefore, TSWV was concentrated step by step.

We thank Drs. Takanami, Y. and Kubo, S., Japan Tobacco Inc., for their collaboration in preliminary study of identification of the virus. We wish to thank Dr. Tanaka, T., Japanese Red Cross Blood Center, Saitama branch, for his help in some of the electron microscopy. We also thank Drs. KameyaIwaki, M. and Hanada, K., National Agriculture Research Center, for critically reading the manuscript.

\section{Literature cited}

1. Amin, P.W., Reddy, D.V.R. and Ghanekar, A.M. (1981). Transmission of tomato spotted wilt virus, the causal agent of bud necrosis of peanut, by Scirtothrips dorsalis and Frankliniella schultzei. Plant Dis. 65: 663-665.

2. Best, R.J. (1968). Tomato spotted wilt virus. Adv. Virus Res. 13: 65-146.

3. Black, L.M., Brakke, M.K. and Vatter, A.E. (1963). Purification and electron microscopy of tomato spotted wilt virus. Virology 20: 120-130.

4. Francki, R.I.B. and Hatta, T. (1981). Tomato spotted wilt virus. In Handbook of Plant Virus Infections and Comparative Diagnosis (Kurstak, E. ed.). Elsevier-North-Holland Biomedical Press, Amsterdam. pp. 491-512.

5. Gumpf, D.J. and Weathers, L.G. (1972). Identification and purification of tomato spotted wilt virus isolated from ageratum. Plant Dis. Reptr. 56: 869-872.

6. Ie, T.S. (1970). Tomato spotted wilt virus. CMI/AAB. Descriptions of Plant Viruses No. 39.

7. Ie, T.S. (1971). Electron microscopy of developmental stages of tomato spotted wilt virus in plant cells. Virology 2: 468-479.

8. Inouye, T. and Inouye, N. (1970). Tomato spotted wilt virus isolated from dahlia. Nōgaku Kenkyu 54: 79-90.

9. Iwaki, M., Honda, Y., Hanada, K., Tochihara, H., Yonaha, T., Hokama, K. and Yokoyama, T. (1984). Silver mottle disease of watermelon caused by tomato spotted wilt virus. Plant Dis. 68: 1006-1008.

10. Joubert, J.J., Hahn, J.S., Wechmar, M.B.V. and Van Regenmortel, M.H.V. (1974). Purification and properties of tomato spotted wilt virus. Virology 57: 11-19.

11. Kameya-Iwaki, M., Hanada, K., Honda, Y. and Tochihara, H. (1988). A watermelon strain of tomato spotted wilt virus (TSWV-W) and some properties of its nucleocapsid. Abstr. 5th International Congress of Plant Pathology, Kyoto. p. 65.

12. Kobatake, H., Osaki, T., Yoshioka, A. and Inouye, T. (1976). Spotted wilt disease of tomatoes in Japan. Ann. Phytopath. Soc. Japan 42: 287-294.

13. Lee, T.C., Francki, R.I.B. and Hatta, T. (1979). A serious disease of gladiolus in Australia caused by tomato spotted wilt virus. Plant Dis. Reptr. $63: 345-348$.

14. Milne, R.G. (1970). An electron microscope study of tomato spotted wilt virus in sections of infected cells and in negative stain preparations. J. gen. Virol. 6: 267-276.

15. Milne, R.G. (1972). Electron microscopy of viruses. In Principles and Techniques in Plant Virology 
(Kado, C.I. and Agrawal, H.O., eds.). Van Nostrand Reinhold Co., New York. pp. 76-128.

16. Milne, R.G. and Francki, R.I.B. (1984). Should tomato spotted wilt virus be considered as a possible member of the family Bunyaviridae? Intervirology 22: 72-76.

17. Mohamed, N.A., Randles, J.W. and Francki, R.I.B. (1973). Protein composition of tomato spotted wilt virus. Virology 56: 12-21.

18. Paliway, Y.C. (1974). Some properties and thrips transmission of tomato spotted wilt virus in Canada. Can. J. Bot. 52: 1177-1182.

19. Sakamoto, I. and Matsuo, A. (1975). A virus isolated from green pepper. Ann. Phytopath. Soc. Japan 41: 95 (Abstr.).

20. Tas, P.W.L., Boerjan, M.L. and Peters, D. (1977). Purification and serological analysis of tomato spotted wilt virus. Neth. J. Pl. Path. 83: 61-72.

21. Tomaru, K., Sawa, Y., Suzuki, I., Tanaka, Y., Kuwata, S., Takanami, Y. and Kubo, S. (1984). Occurrence of tobacco stunt virus (TSV), potato virus Y, necrotic strain (PVY-T) and tomato spotted wilt virus (TSWV) on tobacco plants in Tohoku district. Ann. Phytopath. Soc. Japan 50: 113 (Abstr.).

22. Tomaru, K., Takanami, Y. and Kubo, S. (1976). New virus disease occurred on tobacco plants in Okinawa Prefecture. Ann. Phytopath. Soc. Japan 42: 382 (Abstr.).

23. Tomaru, K., Takanami, Y. and Kubo, S. (1982). Occurrence of tomato spotted wilt virus in tobacco plants in Ryukyu islands. Ann. Phytopath. Soc. Japan 48: 336-339.

24. Tsuda, S., Natsuaki, K.T. and Tomaru, K. (1988). Purification and serological study of tomato spotted wilt virus isolated from tobacco plants in Japan. Abstr. 5th International Congress of Plant Pathology, Kyoto. p. 64.

25. Udagawa, A. (1976). Tomato spotted wilt virus isolated from tomato plants in Kanagawa Prefecture. Bull. Kanagawa Agric. Exp. Stn. 116: 45-55.

26. Van den Hurk, J., Tas, P.W.L. and Peters, D. (1977). The ribonucleic acid of tomato spotted wilt virus. J. gen. Virol. 36: 81-89.

27. Verkleij, F.N., de Vries, P. and Peters, D. (1982). Evidence that tomato spotted wilt virus RNA is a positive strand. J. gen. Virol. 58: 329-338.

\section{和 文 摘 要}

津田新哉・夏秋啓子・都丸敬一：タバコから分離されたトマト黄化えそウイルスの精製

1983 年, 岩手県盛岡市のタバュから分離されたウイルスは, トマト, タバコ, Nicotiana benthamiana, ペチュニアおよびササゲなどの植物への汁液接種の結果および電子顕微鏡観察によってトマト黄化えそウイ ルス (TSWV) と確認された。ショ糖密度勾配遠心法を用いて本ウイルスの精製を試みた。はじめに, 感染 葉からのウイルスの抽出を目的として， 7 種類の磨砕用緩衝液を検討した結果， $0.1 \mathrm{M}$ リン酸緩衝液 $(\mathrm{pH}$ 7.0, $0.01 \mathrm{M}$ 亜硫酸ナトリウムと $0.01 \mathrm{M}$ EDTA を含む) は，タバュ葉を用いた半葉法による感染価の検定に よって適当と考えられた。40.0\% (w/w) ショ糖濃度を階段状とした段階ショ糖平衡密度勾配遠心法を行っ た結果, 宿主植物由来の物質のピークと TSWV 感染性のピークとは分離され，TSWV 感染性の最大值を示 す分画には，電子顕微鏡観察で TSWV 粒子が多数観察された。精製各過程に括ける比感染価は，精製の進 行に伴って増大し, 第一段階の感染価に対して最終的には OD260 值で約 44 倍, OD 280 值では約 46 倍とな った。

\section{Plate I}

\section{Explanation of plate}

1. Systemic symptoms of $N$. tabacum cv. Burley 21 by TSWV-M sap inoculation. The arrow shows inoculated leaf.

2. Local lesions on inoculated leaf of N. tabacum cv. Xanthi nc.

3. Electron micrograph of TSWV particles with envelope in the dip preparation of systemically infected N. tabacum cv. Burley 21. Bar indicates $100 \mathrm{~nm}$.

4. Ultrathin section of a mesophyll cell of systemically infected N. tabacum cv. Burley 21. Bar indicates $200 \mathrm{~nm}$.

5. Electron micrograph of purified TSWV in the fraction with $42.0 \%(\mathrm{w} / \mathrm{w})$ sucrose concentration following isopycnic step-wise sucrose density gradient centrifugation. Bar indicates $100 \mathrm{~nm}$. 


\section{Plate I}
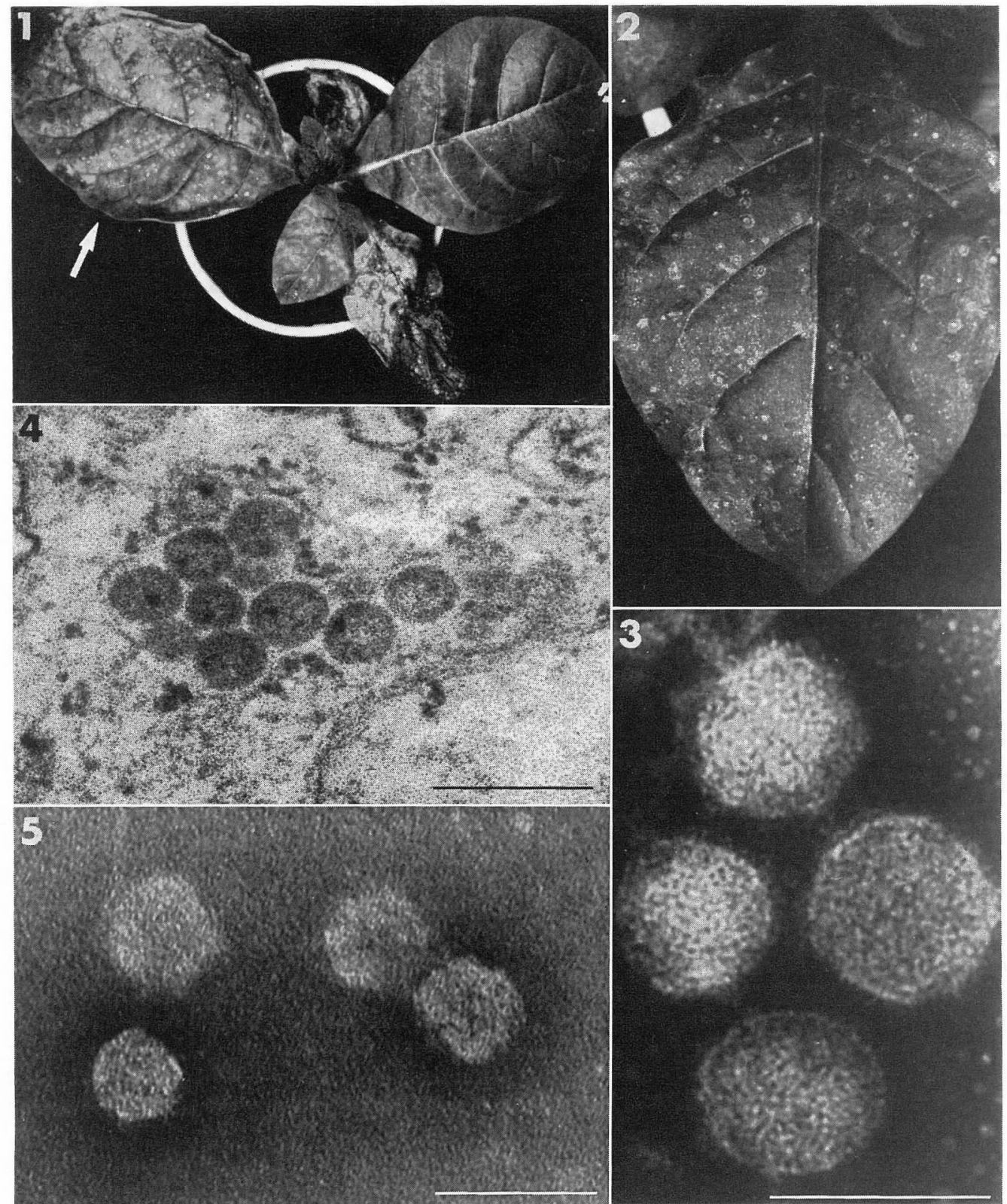